\title{
Geopolitics and Information Warfare: Russia's Approach
}

This article explores the viewpoint prevailing among Russian researchers in respect to the transformation of geopolitics in the Information Age. It focuses on the changes in the concepts of power and space, which resulted in the emergence of information geopolitics as an important problem for scientific analysis. The article discusses information warfare, which is perceived in Russia as a tool for implementing modern geopolitical strategies. Traditional manipulation techniques and mediagenic crisis scenarios are analysed. The concept of a national information culture, which performs the function of protecting modern society from information attacks, is also introduced in this article. A tendency has recently emerged in information warfare studies and practical politics to deal with the problem of information security by imposing traditional bans and restrictions. Since such an approach does not suit open democratic societies, this article proposes alternative methods of addressing information security issues.

\section{Preface}

The information revolution, globalisation, ${ }^{1}$ and internationalisation ${ }^{2}$ have transformed modern international relations. They are now developing within a global information environment, ${ }^{3}$ where new principles of political cooperation, competition, or conflicts between the subjects of an international system are set out. In this environment, political processes occur in real time, geographic barriers lose their former significance, and the very concept of geopolitics is changing. With Lithuania determined to become a dynamic actor on international arena and with a view of successfully attaining Lithuania's foreign policy goals, it is necessary to understand how modern geopolitics is perceived in Russia, a country which exerted and continues to exert a strong influence on Lithuania.

\footnotetext{
* Nerijus Maliukevičius is a PhD candidate, Institute of International Relations and Political Science, University of Vilnius. Address: Vokiečių 10, LT-01130 Vilnius, Lithuania, tel. +370-5-2514130, e-mail: maliukevicius@yahoo.com

${ }^{1}$ Globalisation means a worldwide consolidation of information and technological standards, management and production patterns, and assimilation of social and political structures, cultures and values, promoting the creation of joint institutions and regimes.

${ }^{2}$ Internationalisation means an increasing interconnection between different subjects of international relations, uniting them into a single community wherein national and cultural identity is preserved.

${ }^{3}$ Global information environment means interacting or conflicting states, institutions, cultures or religions interconnected by information, telecommunications or media links which are unrestricted by geographical or time barriers.
} 
In Lithuania, geopolitical discourse is very popular. The notion of geopolitical code, put forward by Raimundas Lopata and Vytautas Žalys, is discussed vigorously. ${ }^{4}$ It is important that these studies are carried out within the context of geopolitical strategies developed by Lithuania's neighbours. ${ }^{5}$ However, they need to develop an information dimension, ${ }^{6}$ which is the pivot of the information geopolitics pursued in Russia.

The concepts of geopolitical power and geopolitical space can be easily distinguished in Russia's modern geopolitical interpretations. Russian experts in information geopolitics, Igor Panarin ${ }^{7}$ and Andrei Manoilo. ${ }^{8}$ underline the impact of soft power based on information and media resources on modern international relations. The global information environment is a new geopolitical arena that greatly differs from the topographic view of the world, which prevailed in traditional geopolitics. Some Russian experts (Sergei Rastorguev, ${ }^{9}$ and Georgi Pochepcov ${ }^{10}$ ) propose to use information warfare tools in the newly emerged environment.

Within this context, information warfare emerges as yet another tool for attaining foreign policy goals, while legal, moral, or ethical aspects of such activity remain in the background. An analysis of this phenomenon is particularly topical for social sciences, aiming to present the most objective social view of the world, because information warfare has a completely different objective, which is to create through the distortion of reality, a favourable political, cultural, psychological, and information environment for the purpose of attaining specific political goals.

\footnotetext{
${ }^{4}$ Raimundas Lopata ir Vytautas Žalys. Lietuvos geopolitinis kodas. Politologija, Nr. 1 (6), 1995, 13-21.

${ }^{5}$ Česlovas Laurinavičius, Egidijus Motieka, Nortautas Statkus. Baltijos valstybiu geopolitikos bruožai: XX amžius. Lietuvos istorijos instituto leidykla, 2005.

${ }^{6}$ Geopolitikos akiračiai (Žygimantas Vaičiūnas (comp.) Geopolitikos akiračiai. Vilnius: Eugrimas, 2004) published in 2004, a study where the concepts of geoculture, Internet geopolitics and information security are analysed, could be considered as the first attempt by Lithuanian researchers to depart from the traditional framework of this discipline.

${ }^{7}$ Игорь Панарин, Технология информачионной войны. КСП+, 2003; Игорь Панарин, Информационная война и мир. Олма-Пресс, 2003; Игорь Панарин, Информачионная война и дипломатия.Городец, 2004.

${ }^{8}$ Манойло А.В. Государственная информаџионная политика в особых условиях. Москва, 2003. http:// www.psyfactor.org/lib/psywar27.htm 02112006

${ }_{9}$ Расторгуев С.П. Информационная война. Радио и связь, 1999. http://www.bookap.by.ru/psywar/infowar/oglav.shtm 0211 2006;

Расторгуев С.П. Инфицирование как способ защиты жизни. 1996. http://www.koob.ru/rastorguev/virus 02112006

${ }^{10}$ Почепцов Г. Г. Информационные войны. Киев: Ваклер, 2000.
} 


\section{Transformation of Geopolitics}

\subsection{Modern Power Levers}

The end of the Cold War, according to Ian Clark, gave rise to new forms of power. ${ }^{11}$ Susan Strange points out that the state looses its monopoly on power in a modern international environment affected by globalisation. ${ }^{12}$ Large corporations, non-governmental organizations and other non-state subjects are gaining an ever-increasing influence. Other authors emphasize the ongoing fragmentation of sovereignty. Patrick Tyrrell predicts that linguistic, religious, or cultural forms of sovereignty will develop alongside national sovereignty within the global information environment, which will not necessarily coincide with state territorial borders. ${ }^{13}$ A question thus arises: who will be the sovereigns of the newly formed sovereign environments?

Robert O. Keohane and Joseph S. Nye contend that the states will retain their sovereign status if they succeed in adapting to the realities of the Information Age and if they are able to wield soft power. ${ }^{14}$ Keohane and Nye define soft power as "the ability to get the desired outcomes because others want what you want." 15 Such power differs radically from the traditional military power that dominated during the Cold War.

The concept of soft power has been borrowed by Russian researchers from their Western fellow colleagues and translated into a framework concept of information geopolitics. Information, information technologies, and the media are most likely to emerge as the crucial power resources of the $21^{\text {st }}$ century. American political theorist James Burnham pointed out that a new managerial class, rather than the working class, was replacing the old capitalist class as the dominant power in post-industrial society. ${ }^{16}$ The new elite were the managers of information and knowledge. As early as in the middle of the $20^{\text {th }}$ century, the Frankfurt School thinkers and scholars described them as the "managers of public opinion."17

In the future, effective foreign policy will depend more increasingly on the popularity and public appeal of state-promoted ideas. To form successful coalitions and secure support for international initiatives, the states will have

\footnotetext{
${ }^{11}$ Ian Clark, Globalization and Fragmentation: International Relations in the Twentieth Century. Oxford University Press, 1997, 196.

${ }^{12}$ Susan Strange, The Retreat of State: the Diffusion of Power in the World Economy. Cambridge University Press, 1996.

${ }^{13}$ Patrick Tyrrell, The Information Revolution. Netherlands Annual Review of Military Studies (NLARMS): Information Operations, ed. J.M.J Bosch, H.A.M.Luiijf, A.R. Mollema. Haveka BV, 1999, 73.

${ }^{14}$ Keohane R. O., Nye J. S. Power and Interdependence in the Information Age. Foreign Affairs, No.5 (77) 1998. http://www.ksg.harvard.edu/prg/nye/power.pdf 02112006

${ }^{15}$ Ibid.

${ }^{16}$ Michael Rush, Politics and Society: an Introduction to Political Sociology. Harvester Wheatsheaf, 1992, 65.

${ }^{17} \mathrm{Jim}$ R. Macnamara, Mass Media Effects: a Review of 50 Years of Media Effects Research. CARMA White paper, 2003, 2. http://www.masscom.com.au/Downloads/Media_Effects_(A4).pdf 02112006
} 
to adhere to the principles of public relations or political marketing. ${ }^{18} \mathrm{We}$ could say that the distinctive features of powerful and influential actors on the modern international arena are changing. Such changes can be illustrated by Niccoln Machiavelli's division of the elite into "foxes" and "lions" - which was later on borrowed by Vilfredo Pareto for his elitist social policies:

\section{Table 1. Machiavelli's Distinctive Personal Qualities of the Elite in Pareto's Theory}

\begin{tabular}{|c|c|}
\hline Foxes & Lions \\
\hline Intelligent & Prone to confrontation \\
Manipulative & Resolute \\
Imaginative & Principled \\
Consensus seeking & Reliable \\
Flexible & Impatient \\
Determined & Merciless \\
Enduring & Unyielding \\
\hline
\end{tabular}

Source: Rush, (Note 16) 64.

Pareto's principle of the rise and fall of the elites has now re-emerged on the international arena: the "lions" and their distinctive features that dominated the international relations of the Cold War period are replaced by the "foxes" of the Age of Information, i.e. the states, which are capable of effectively manipulating information to enforce their preferences, resort to persuasion in their policies; they are flexible but also resolute in attaining popularity for their policies, values and cultures.

For modern geopolitics, social and communication resources (TV channels, radio, and the press) acquire the same scope of significance as natural resources (crude oil and natural gas). Control over the telecommunications market has become very important and leads to fierce economic and political struggles for media control in both, the internal market and the global information environment. Vygantas Žyle notes that power is transformed into communication structures, which emerge as the only expression of power. ${ }^{19}$

\subsection{The New Geopolitical Environment}

It is not only the concept of power that undergoes a major change in the Information Age; the understanding of space changes as well. In his analysis of the information society, Frank Webster underlines its multi-dimensional

\footnotetext{
${ }^{18}$ Stephan C. Henneberg, Political Marketing Theory. Working Paper Series, University of Bath, 2004. http://www.bath.ac.uk/management/research/pdf/2004-01.pdf 02112006

${ }^{19}$ Vygantas Žylè, Sukonstruotos ideologijos tikrovè. Informacijos mokslai. Nr. 13, $2000,31$.
} 
characteristics and identifies the following aspects of importance to modern geopolitics:

- Technological, which focuses on the diffusion of information technologies and the tendency of declining operating costs;

- Economic, which focuses on the knowledge economy and its impact on the competitiveness of modern societies;

- Occupational, which focuses on the increasing supply of jobs in the information sector;

- Spatial (information flows), which focuses on worldwide information networks, reshaping the meaning of geographic borders and time;

- Cultural, which focuses on the role of intermediaries in the process of creating and spreading information and on the tendency of information growth, resulting in problems of social reality interpretation. ${ }^{20}$

It is namely the spatial and cultural aspects of the information society that has attracted the attention of experts in information geopolitics. Alvin Toffler points out that capitalist societies, entering the post-industrial age, create "information infrastructures where messages and news are distributed as effectively as products and natural resources in the Industrial Age." ${ }^{21}$ A new environment is being created as a result of globalisation. Frank Webster describes globalisation as a merger of markets, currencies and corporations..$^{22}$ This phenomenon could be also described, in broader terms, as the global consolidation of IT standards, management, and production patterns as well as global assimilation of social and political structures, cultures and values. When analysing the information environment within the context of globalisation, its global and universal aspect is emphasized. However, the global information environment is not homogeneous. In addition to the information environment within a state, there also exist information environments in various cultures and religions. Therefore the global information environment should be also analysed against the background of networking the differences or internationalisation. This process may be defined as a progressively intensifying interconnectivity between different subjects of international relations, uniting them into a single community where distinct national, cultural or religious features are preserved.

By emphasizing not only similarities but also differences, attention is given to the fact that relationships in this environment can range from cooperation to conflict; providing for different tools to be used for attaining specific goals.

\footnotetext{
${ }^{20}$ Frank Webster, Informacinès visuomenés teorijos. Vilnius: Poligrafija ir informatika, 2006, 14-27.

${ }^{21}$ Alvin Toffler, The Third Wave. Bantam Books, 1980, 35.

${ }^{22}$ Webster, (Note 20) 75.
} 


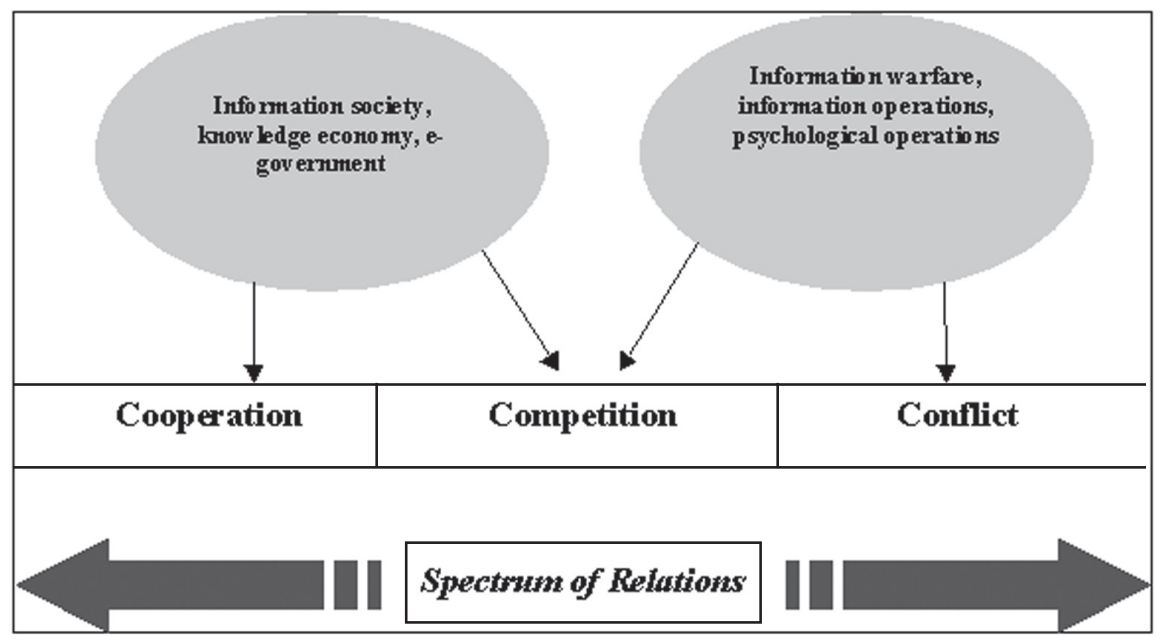

\section{Figure 1. Spectrum of Relations in Global Information Environment and Tools Used}

The search for a modern geopolitical balance is conducted in the global information environment (GIE) ${ }^{23}$ (see Figure 2). The representatives of the Canadian security and war studies' community introduced the concept of this environment. ${ }^{24}$ however, they were mostly interested in its impact on modern military conflicts. Other authors distanced themselves from military aspects and presented their vision of a global information environment comprised of the following elements: ${ }^{25}$

- information systems, which include communication networks (information transmission tools), telecommunication broadcasting technologies (information presentation tools) and software (consumer-friendly information processing and presentation solutions);

- information;

- people.

\footnotetext{
${ }^{23}$ The following terms are used: global information environment or global information infrastructure [N.M.].

${ }^{24}$ Garigue R., Romet T. Information Warfare and the Canadian Forces. National Defence, May, 1996. http:// www.iwar.org.uk/iwar/resources/canada/iw_\&_cf.pdf 02112006

${ }^{25}$ Andy Jones, Gerald L. Kovacich, Perry G. Luzwick, Global Information Warfare: How Businesses, Governments, and Others Achieve Objectives and Attain Competitive Advantages. Auerbach Publ., 2002, 56.
} 


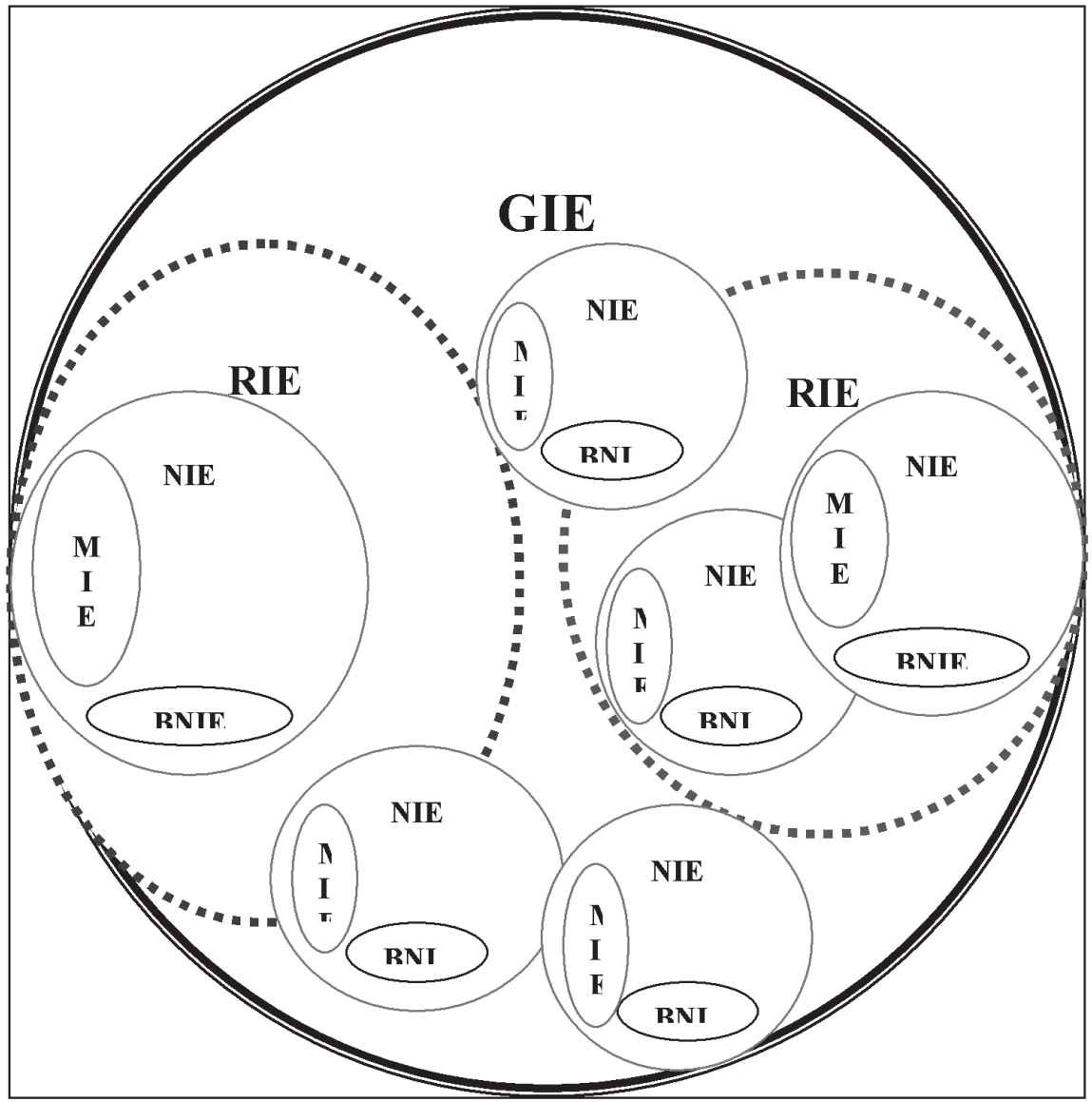

Source: Adapted scheme. See Jones, Kovacich, Luzwick, (Note 25) 62.

\section{Figure 2. Global Information Environment ${ }^{26}$}

Ivan Zassoursky, who analyses changes in the media environment, points out that the traditional Gutenberg Galaxy has been expanded by the e-media and the Internet to a global extent, joining states, cultures, and religions in a single information network. ${ }^{27}$ John Arquilla and David Ronfeldt describe this infrastructure as "noosphere." ${ }^{28}$ In their opinion, it also includes cyberspace and media space. ${ }^{29}$ Panarin also uses this term and for him, noosphere is a

\footnotetext{
${ }^{26} \mathrm{GIE}$ - global information environment; RIE - regional information environment; NIE - national information environment; BNIE - basic national information environment; MIE - military information environment. ${ }^{27}$ Ivan Zassoursky, Media and Politics in Russia in the Nineties. East Political Science Review, No. 6, 2000. http://www.polito.ubbcluj.ro/EAST/East6/zassoursky.htm 02112006

${ }^{28}$ From the Greek noos meaning mind [N.M.].

${ }^{29}$ John Arquilla, David F. Ronfeldt. The Emergence of Noopolitik: Towards An American Information Strategy. RAND Corp., 1999, 4.
} 
pseudo real space in which Russia' geopolitical conceptions that produce real political impact can be modelled. ${ }^{30}$

The global information environment (GIE) means interactive or conflicting national information environments (NIE) as well as regional information environments (RIE) based on culture, religion, and or politics, ${ }^{31}$ which are interconnected by information, telecommunications, and media links. The basic national information environment (BNIE) is the backbone of the existence of the state. In times of military conflict, the military information environments (MIE) acquire a very special meaning and importance. Russian experts maintain that the core of a state comprises not only technical systems, but also those systems, which are based on social and psychological interrelations:

- national cultural heritage, patriotism and values;

- ability to effectively communicate Russia's official policies on various issues to local and international society. ${ }^{32}$

Some authors ${ }^{33}$ say that currently 53 countries in the world officially discuss their information environments (NIE), ${ }^{34}$ analysing and improving them to ensure their security and stability.

Representatives of information geopolitics are particularly interested in regional information environments (RIE). All of the other elements of the global information environment are built on a national geographic basis, while regional information environments have their roots in area-based cultures, values, religions, and businesses. ${ }^{35} \mathrm{John}$ Arquilla and David Ronfeldt have developed the notion of a new kind of politics, noopolitics, based on active information politics. ${ }^{36}$ Along this line of reasoning, the concept of post-Soviet space emerges as a geopolitical battlefield for Russian geopoliticians. ${ }^{37}$ It reveals yet another aspect to the phenomenon of "fellow nationals" (соотечественники,- rus.) ${ }^{38}$ and the work carried out by the institutions specially established to deal with relating issues. ${ }^{39}$

\footnotetext{
${ }^{30}$ Панарин, Информационная война и дипломатия, 176.

${ }^{31}$ Examples of regional information environments: "post-Soviet space", "European space", "Oriental culture ", "Islam world", etc. [N.M.]

32 Доктрина информационной безопасности Российской Федерации. http://www.scrf.gov.ru/documents/ decree/2000_pr-1895.shtml 02112006

${ }^{33}$ Jones, Kovacich, Luzwick, (Note 25) 56.

${ }^{34}$ Terms may differ: national information infrastructure, national information environment (En.) and other. [N.M.]

${ }^{35}$ Jones, Kovacich, Luzwick, (Note 25) 61.

${ }^{36}$ Arquilla, Ronfeldt, (Note 28) 34.

${ }^{37}$ В. В. Разуваев, Геополитика постсоветского пространства РАН. Ин-т Европы, 1993.

${ }^{38}$ Игорь Панарин, Информационная поддержка соотечественников. http://www.panarin.com/ 0211 2006

${ }^{39}$ Department for Interregional and Cultural Relations with Foreign Countries at the Administration of the President of the Russian Federation was established in March of 2005; it is headed by Modest Kolerov. See http://document.kremlin.ru/doc.asp?ID=027071 02112006
} 


\subsection{From Classical to Information Geopolitics}

Geopolitics is defined as the "transformation of power in geographic space." 40 The current changes in the concepts of power and space provoke discussions about their potential to modify the overall concept of geopolitics. At the beginning of the $20^{\text {th }}$ century, geopolitics was directly related to political geography. A complete geographic picture of the world was formed. Therefore, a search began for the geographical pivot of the world, the control of which would provide the state with immense power. Halford Mackinder placed the pivot area in the Heartland of Eurasia, ${ }^{41}$ while Alfred Thayer Mahan contended that domination of the sea via naval power was the deciding factor. ${ }^{42}$ These geopoliticians created the traditional foundation for geopolitics: the never-ending dispute between the sea power and the land power. Nicholas Spykman and Karl Haushofer joined the dispute later on. ${ }^{43}$ It should be noted that classical geopolitics introduced the principle of dichotomy into international politics: the polarity between sea and land was subsequently replaced by a polarity between North and South, capitalism and communism, Christianity and Islam.

The founders of geopolitics were influenced by geographical determinism; therefore they constrained state politics and their development by topographical frames. Subsequent representatives of classical geopolitics realized that the boundaries of this discipline were being changed and reshaped by technological progress: discussions started about controlling air power ${ }^{44}$ and aerospace power..$^{45}$ The development of geopolitics was shaped not only by a more extensive and deeper knowledge of the physical world, but also by a more persistent focus placed by some geopoliticians on the social world. Structural and, at times, topographical analysis of history, economy, culture, and psychology resulted in the creation of maps of civilizations, cultures, and religions. The works by Samuel Huntington and Francis Fukuyama are sometimes described as new trends in classical geopolitics. Although the concepts of the "clash of civilizations" and the "triumph of liberal capitalism," which emerged after the Cold War, offers an innovative outlook on geopolitical problems, they are nevertheless attributed to classical geopolitics:

The response given by some international relations analysts to the challenges of modern international politics does not transgress the boundaries of classical geopolitics. ${ }^{46}$

\footnotetext{
${ }^{40}$ Laurinavičius, Motieka, Statkus, (Note 5) 13.

${ }^{41}$ Александр Дугин. Основы Геополитики. Москва: Арктогея, 2000. http://www.geopolitika.ru/geopol1. $\underline{\mathrm{htm} \# 3} 02112006$

42 Дугин, http://www.geopolitika.ru/geopoll.htm\#4 02112006

${ }^{43}$ Дугин, http://www.geopolitika.ru/geopoll.htm\#6 02112006

${ }^{44}$ Giulio Douhet, Hugh Montague Trenchard, William (Billy) Mitchell.

${ }^{45}$ Everett Carl Dolman, Astropolitik: Classical Geopolitics in the Space Age. Frank Cass Publ., 2002.

${ }^{46}$ Rimas Ališauskas, Interneto geopolitika. Žygimantas Vaičiūnas (sud.) Geopolitikos akiračiai. Vilnius: Eugrimas, 2004, 15.
} 
For modern representatives of classical geopolitics, both the physical world and social world are definitive and distinct. They do not accept criticism that such worlds are created by separate people, societies, non-governmental organizations, transnational corporations, media conglomerations, and countries for their own benefit and also for the purpose of gaining power. The era of great geographical discoveries ended long ago but social reality will never end - it is to a certain extent moulded and shaped. The information society has access to social resources, which differ radically from the resources prevailing in the industrial society. Besides, information technologies and new means of communication have created the necessary conditions for stepping over the boundaries of the physical world and building a "media reality," simulating identities, and joining virtual societies without geographic boundaries. ${ }^{47}$

In the $20^{\text {th }}$ century, French geopolitical researcher Paul Vidal de la Blache pointed out that in addition to the geographic factor, the human factor was just as important in geopolitics. Human activity is based on initiative, values, wishes, and aspirations that predetermine the use or disregard of the geographic factor. ${ }^{48}$ Earlier, if an initiative launched by the state or society encountered political and geographical barriers, the usual solution for eliminating them would be resorting to traditional military force, like Nazi Germany did to control the Heartland. However, the information revolution has made it possible for any political initiative, launched either individually or by the state, to be displayed across the global information environment where traditional military conflicts have been replaced by information conflicts.

For modern representatives of geopolitics, the transformation of power in space means a confrontation within the framework of the global information environment between societies and the states with highly developed information technologies and means of communication. There are other tools and devices, besides military weapons, for dividing this space.

Russia's modern geopolitical projects also include the ideas of Zapadniks (westernisers), Pan-Slavists and some elements of the Eurasian perspective of a great new state. ${ }^{49}$ They are different in many aspects but all of them are built on dual ideas. First, we should distinguish the neo-imperial discourse, ranging from incitements to expand Westwards and South Westwards to proposals for a political and ideological consolidation of the state, i.e. withstanding the post-Soviet "cycle of collapse" and concentrating all power and resources for a new cycle of the empire's expansion..$^{50}$ Such expansion does not relate to traditional geopolitical visions of enlargement, it rather relates to information

\footnotetext{
${ }^{47}$ Virtual social communities, Internet communities, network social communities, and virtual coalitions have become the object of research. See Cristiano Castelfranchi, Tan Yao-Hua. Trust and Deception in Virtual Societies. Kluwer Academic Publ., 2001.

${ }^{48}$ Дугин, http://www.geopolitika.ru/geopol0.htm\#1 02112006

${ }^{49}$ Raimundas Lopata ir Nortautas Statkus, Empires, the World Order and Small States. Lithuanian Foreign Policy Review, No. 1-2 (15-16), 2005, 40.

50К барьеру: Дуэль Павловского и Белковского. Интегрум, 20050325 http://kreml.org/other/82246730 02112006
} 
expansion, which is now actively discussed by Panarin. ${ }^{51}$ Second, such projects place a special emphasis on the Russian Orthodox Church. It is the religious aspect that allows geopoliticians to speak about the "Russian civilization" or the Third Rome. Statements are made to the effect that the Church was separated from the media in past decades; therefore it should regain its communication levers $^{52}$. Alexander Dugin has taken yet another step in this direction and now works in the religious information environment. ${ }^{53}$

Panarin claims that he is the author of the concept of information geopolitics, ${ }^{54}$ which places primary importance on fighting for information levers instead of geographical territory. Manoilo also gives marked attention to these issues. Manoilo says that national information environments may clash, cooperate and compete. The state may effectively penetrate into the environment of another state and manipulate its public opinion only where both environments operate a common code (language, religion, historical experience, etc.). ${ }^{55}$ Otherwise, a confrontation is provoked which may result in extreme manifestations. According to Manoilo, dominance in the information environment of a geopolitical adversary can be ensured only through the use of such tools as: ${ }^{56}$

- Latent information management of the opponent's internal, economic and cultural processes - which would create the required background for information, ideological, economic, and cultural expansion and predetermine the opponents' decisions beneficial for the manipulator.

- Information-psychological aggression based on economic, political and diplomatic pressure. E.g. the wine blockade of Georgia and Moldova is accompanied by intense information-psychological attacks. ${ }^{57}$

- Information war based on economic blockade and threat of use of force. Russia resorted to this tool after the arrest of Russian servicemen in Georgia ${ }^{58}$. Russia continues to deploy its troops not only in Georgia but also in other post-Soviet areas, which allows it to use traditional military force in addition to information war levers when dealing with "frozen military conflicts."

The technological dependency of the state and the psychological dependency of society on the information resources manipulated by another state, encourages a subtle or aggressive information expansion; the range and variety of potential influence tools and techniques can be illustrated by the following model of information flows as designed by Renaldas Gudauskas:

\footnotetext{
${ }^{51}$ Игорь Панарин, Евразийская Русь - Информационная Империя. http://www.panarin.com/comment/465 02112006

52 Глеб Павловский, Идеология: Наша информационная доктрина. 20000928 http://www. strana.ru/about/02.html 02112006

${ }^{53}$ Alexander Dugin is the Vechi programme author and presenter at the TV network Spas. See http://vehi. tv and http://www.spastv.ru 02112006

${ }^{54}$ Дмитрий Тымчук, Информационная геополитика: от теории до практики. http://www.panarin.com/ comment/249 02112006

${ }_{55}^{5}$ Манойло, (Note 8) 76.

${ }^{56}$ Ibid, 17.

${ }^{57}$ See news column: Запрет на ввоз молдавских и грузинских вин и минеральной воды в Россию. Regnum, http://www.regnum.ru/dossier/833.html 02112006

${ }^{58}$ See news column: Обострение отношений между Россией и Грузией. Regnum, http://www.regnum. $\underline{\mathrm{ru} / \mathrm{dossier} / 1056 . \mathrm{html}} 02112006$
} 


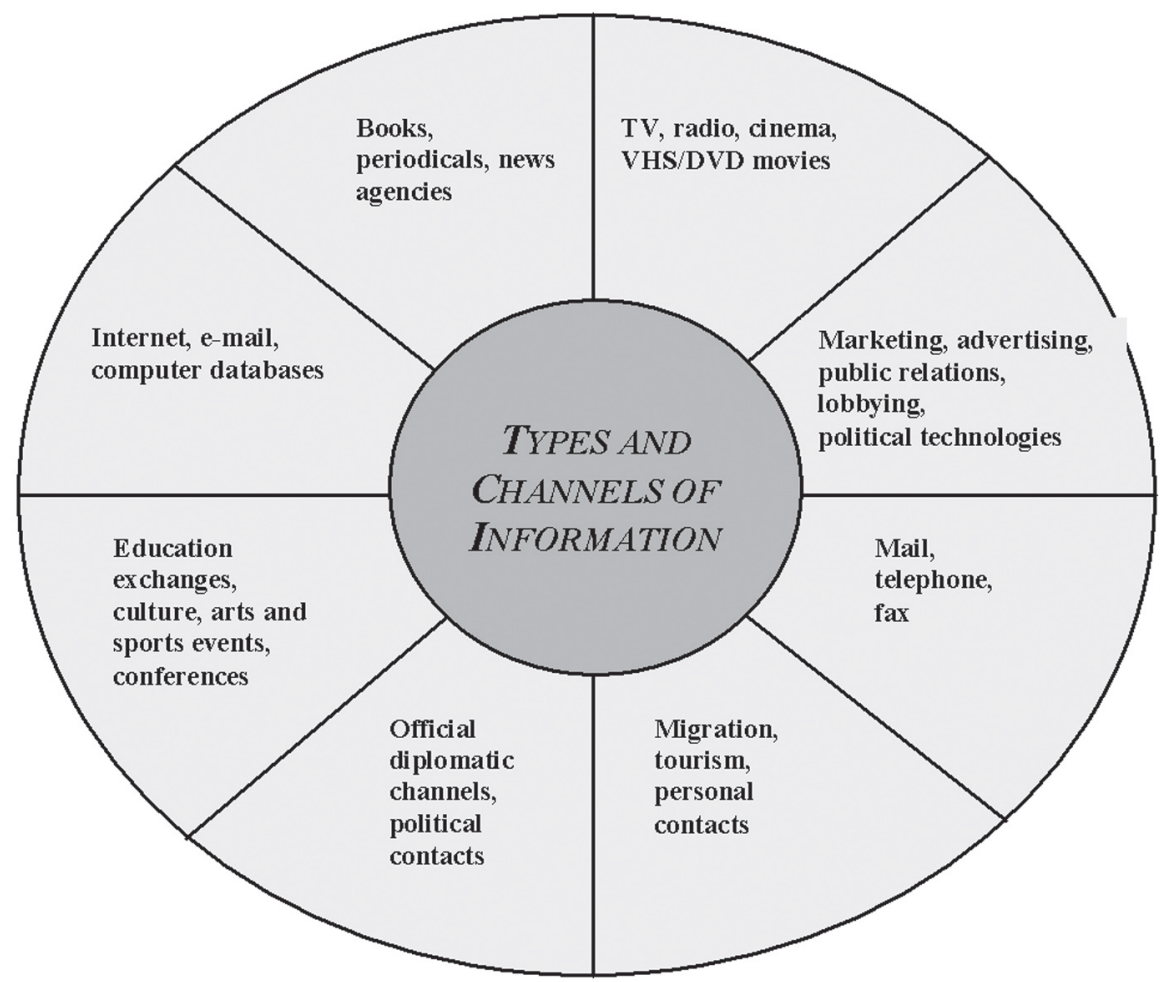

Source: Adapted model by Renaldas Gudauskas. See Renaldas Gudauskas, Valstybės informacijos strategijos Lietuvos įvaizdžio kūrimo srityje matmenys. Informacijos mokslai, Nr. 6 (1), 1997.

\section{Figure 3. Model of Information Flows}

The above scheme does not comprise a complete list of information channels, tools, and techniques, but it nevertheless illustrates the enormous complexity of this process. Manoilo underlines that in each state there exists a specific national system of creating and disseminating information - which is predetermined by the language, cultural, and religious aspects of receiving and understanding information. ${ }^{59}$ The information environment of the state comprises a specific information-telecommunications infrastructure, relevant information resources, telecommunications, principles regulating the media and entertainment business in the relevant country, and also its regulatory legal framework. Therefore, one of the most important factors predetermining the efficiency of information geopolitics is deep and expert knowledge of the information environment of other states. It is only after the relevant environment is studied in detail that the respective communication tools and information influence techniques are decided on. To this end, a special focus is made in information geopolitics on effective monitoring systems 
directed at the neighbouring information environments and on the required intellectual resources.

Manoilo proposes to use the following criteria ${ }^{60}$ based on which it would be possible to determine the efficiency of information geopolitics:

- Ability to efficiently control ones own segment of the information environment; this includes the level of development of the information infrastructure, a quantitative and qualitative expression of information and knowledge, and also independence (economic and cultural) from foreign telecommunications structures and strategic information.

- Ability to ensure the security of ones own information environment from the information expansion and attacks by opponents.

- Ability to expand ones own influence in the global information environment, which depends on the ability to pursue an active information policy in respect of opponents.

- Ability to bring together allies for the purpose of an information battle and the ability to form "information coalitions".

In addition, there exist factors that weaken the resilience of the national information environment against information expansion, these being: disorientation of information policy, indefinite political priorities, and also a blurred vision of the national state. Such a situation creates conditions for destabilizing the political situation inside the state by information attacks, at the same time enforcing externally designed solutions to deal with a crisis. It is quite obvious that such solutions will suit only the influencing state. In his monograph, Manoilo contends:

Information-psychological expansion is an activity which pursues national interests through penetrating by non-conflict methods the social and cultural relations within society. The ultimate objective is to consistently and gradually modify, without the knowledge or awareness of society, the system of social relations and tailor it for the needs of the influencing party. Information attacks are directed at the established ideology and aimed at replacing national values with the values and ideological stance of the influencing party. The following tools are applied: the control and regulation of strategic resources, information-telecommunications structures, and the media market" ${ }^{\prime \prime 1}$.

The representatives of information geopolitics thus take a different approach to power than classical geopolitical researchers. The latter see power as the management of various spheres of life (politics, economy) as delineated by political geography, i.e. the state's territory and borders. Modern geopolitical analysts define power as the management of the information sphere based on knowledge, information infrastructure control, and public opinion influencing techniques. ${ }^{62}$

\footnotetext{
${ }^{60}$ Ibid, 272.

61 Ibid, 303.

${ }^{62}$ Владимир Попов. Коммуникативная и социальная природа и функция власти. http://www.informanalytic.ru/images/stories/text/popov5.zip 02112006
} 


\section{Information Warfare as Instrument of Modern Geopolitical Battles}

\subsection{Information Warfare Target: Information Culture within the State}

German geopolitician Friedrich Ratzel argued that states were like living organisms, ${ }^{63}$ seeking to grow in size. Ratzel compared their territorial borders and geographical boundaries to human skin, performing the protective functions of the organism. In the Information Age, the protective functions of the state are fulfilled not only by its borders, but mostly by the dominant world outlook within the information environment such as: it serves as an information filter or a meta-structure which helps society to understand, select, classify or reject information about itself or the outer world. Information geopolitics, with the help of military tools, has the immediate objective of penetrating this filter. In their studies, Pochepcov and Rastorguev make a strong focus on such actions. The first analysed the problem of influence effectiveness, underlining that internal influence was always more effective than external influence. ${ }^{64}$

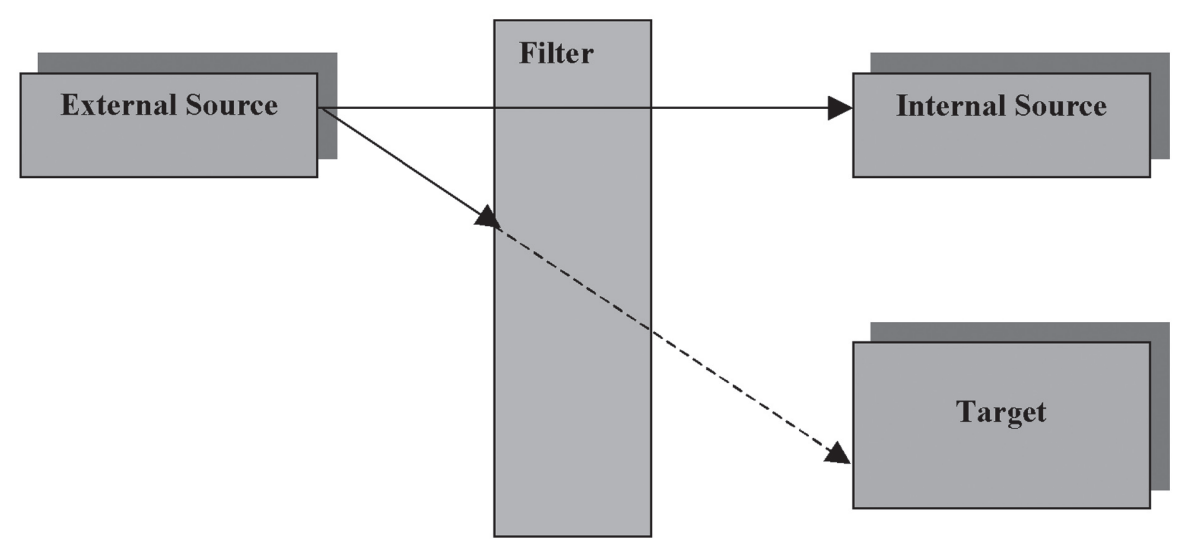

Source: Georgi Pochepcov's model. See Почепцов, (Note 10) 502.

\section{Figure 4. Providing Information by Eluding the Filter}

Pochepcov's model may be explained on the basis of an individual person's psychological protection, which means that a person dissociates himself from information that, in his opinion, is not in conformity with his moral or spiritual values and can destroy the nucleus of his personality. Juri Kolin, a Russian expert in information warfare, maintains that a "similar element of

\footnotetext{
${ }^{63}$ Дугин, http://www.geopolitika.ru/geopol1.htm\#1 02112006

${ }^{64}$ Почепцов, (Note 10) 502.
} 
psychological protection also exists in society which, in an effort to escape disintegration, rejects and discards from its collective consciousness any information contravening the established world outlook and national identity." ${ }^{65}$ It is said that such a filter performs the function of social immunity. In every state, there exist unique technical and cultural structures, which help to assimilate information and thus create awareness. Information warfare has the objective of penetrating them for the purpose of influencing society from the inside.

Such a society protection mechanism became the object of Rastorguev's analysis ${ }^{66}$ Rastorguev compares information warfare to an information infection and analyses it within the context of biological, computer and social infections.

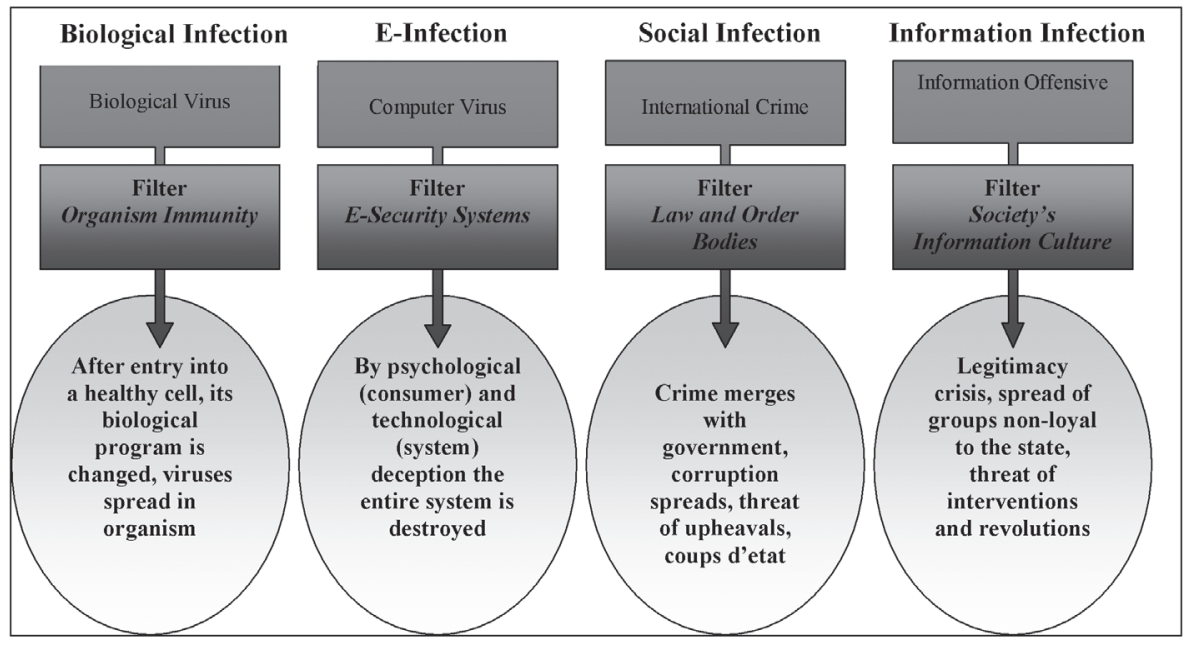

Figure 5. Principle of Neutralizing Protection in Rastorguev's Concept of Information Warfare

In information warfare, it is the weak spots in the society's protection mechanism that are attacked. Such weak spots may be a high disintegration level of society, historical traumas or any weakness of the state and its separate elements (the media, education system, etc.) as well as vulnerability to economic and other tools of influence. Information warfare targets the relationship between society and government as well as relations between different groups of society to create a confidence crisis. Pochepcov maintains that the critical limit in each society is exceeded when "more than 40 percent of the population demand radical changes in the political system and less than 25 percent have

\footnotetext{
${ }^{65}$ Колин Ю. Информационная война: перспективы и стратегии. Научная мысль Кавказа, №. 1, 2003. http://warning.dp.ua/tel7.htm 02112006

${ }_{66}$ Расторгуев, Инфицирование как способ защиты жизни. http://www.koob.ru/rastorguev/virus 0211 2006
} 
confidence in the central government. ${ }^{67}$ In this case, a legitimacy crisis emerges and there emerges a real threat to the entire political system of the state.

Daiva Urbonaite, who analysed the concept of information culture of the state, says that in a modern state there exists a special structure for receiving and assimilating information, which operates in compliance with its own communication standards and rules. This structure performs the functions of a "social and cultural immunity" 68 system. Information culture may be seen as a specific protection mechanism of modern society against the aggressive strategies devised by information geopolitics.

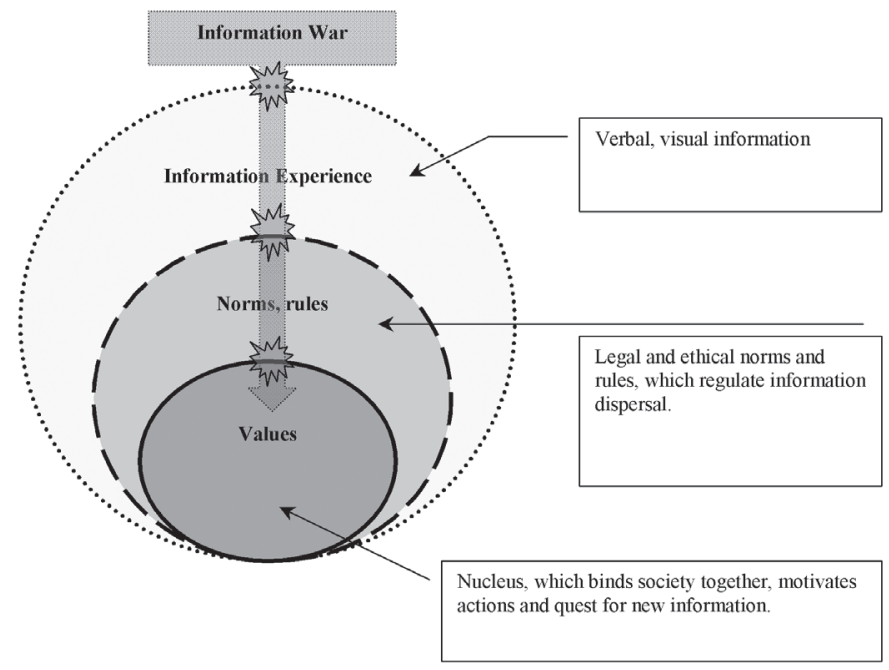

Source: Model by author based on Urbonaite's notion of information culture.

\section{Figure 6. National information Culture and Information War}

Frank Webster describes cultural changes in the Information Age as follows:

Contemporary culture is manifestly more heavily information laden than any of its predecessors. We exist in a media-saturated environment which means that life is quintessentially about symbolization, about exchanging and receiving - or exchange and resisting reception of - messages about ourselves and others ${ }^{69}$.

The nucleus of information culture - values (being political, religious, etc.) - is formed in the process of socialization. In this way, concrete values are established in society, providing for motives to seek further knowledge for daily, occupational, or political activity. But within information society, this nucleus of values is surrounded by specific norms and rules of communication, which

\footnotetext{
67 Почепцов, (Note 10) 24.

${ }^{68}$ Daiva Urbonaitė, „Informacinės kultūros teorinis pagrindimas.” Informaciniai mokslai, Nr. 10, $1999,55$.

${ }^{69}$ Webster, (Note 20) 26.
} 
predetermine the actual way of translating information into knowledge, the mode of the modification of values and emergence of new values. Such norms relate not only to the legal regulation of the media, but also to the code of ethics practiced by journalists, PR specialists, lobbyists, or political consultants. Urbonaite points out that a specific etiquette for communicating has emerged in the information society, ${ }^{70}$ i.e. an understanding of what is appropriate and inappropriate when spreading information. Of course, communication norms differ radically in democratic and totalitarian societies.

Kolin points out that information warfare has the objective of destroying a society's security system and at the same time disseminating within the information environment such information and interpretations that are in dissonance with the existing values, thus injecting instability into the society's spiritual, political, and economic life. ${ }^{71}$ Therefore, any loopholes in the state system of information culture norms and rules as well as in its communication etiquette are primary targets. Specific focus is placed on the legal regulation of information technologies, telecommunications and the media. Market laws and principles are transposed to the media. Motivated information and communication systems are expanded.

We have to admit though that the analogy of information warfare and biological or computer viruses represents a somewhat simplified approach because social and psychological processes are much more complicated than similar biological or computer processes. Such thinking paradigms may lead to the emergence of radical theories. ${ }^{72}$ Besides, politicians and military information experts may be tempted to resolve information security issues through restrictions and prohibitions - which is unacceptable for open democratic societies. Protection from biological or computer viruses is much more easy and simple than resolving the complicated issues relating to the society's information security.

\subsection{Information Warfare Tools: From Traditional Manipulation Techniques to "Mediagenic Crisis"}

Pochepcov points out that advertising is based on the strategy of desire, public relations is based on the strategy of trust and confidence, propaganda on the strategy of persuasion, and information warfare - on the strategy of resonance. ${ }^{73}$ The latter may be described as a "high-profile" communication, which has the objective of creating a disturbance and upheaval in public space, overshadowing all other types of communication. Such a strategy does not target understanding or rationality; it is rather directed towards emotions or impulses. Information warfare is based on three main principles:

\footnotetext{
70 Urbonaite, (Note 68) 60.

${ }^{71}$ Колин (Note 65).

${ }^{72}$ Silver Bullet model in communication science or Pavel Polujan's conception of noovirus.

${ }^{73}$ Почепцов, (Note 10) 9-10.
} 
- attracting attention;

- raising emotions or feelings;

- imposing solutions for crisis settlement.

The success of business or political communication in a modern society depends on the ability to attract the attention of an audience and direct it to specific information. ${ }^{74}$ Various means of information warfare are used to create emotions, a feeling of instability and dissatisfaction in an audience and at the same time to make society choose biased solutions for resolving an artificially created crisis. The techniques of influence used in information warfare are not exceptional or original. In most cases, they are based on propaganda manipulation, studied by scholars at the beginning of the $20^{\text {th }}$ century. ${ }^{75}$ Such communication is based on providing selective information to the political and media elite, as well as ethnic and social groups. In addition, information is provided in doses and only that portion of facts is presented which is beneficial for the influencing person, while the other facts are passed over in silence. Information aggression is built on psychological pressure, meaning that an atypical order is given to act and perform quickly without allowing any time for thinking or using alternative information sources. Such information attacks are usually built on pseudo-events:

A pseudo-event is not spontaneous: it is planned and planted in information soil by someone. [...] A pseudo-event is created for the purpose of being immediately exposed, reported, reproduced, and multiplied. ${ }^{76}$

A pseudo-event is not entirely real; it is a media event staged for the media or by the media and spread across the information space with the help of the media. However such events are real in their consequences, because even though they have a minimal link to objective reality, they make a direct influence on it by motivating society or politicians to perform specific actions.

Information attacks are built on the human need (psychologically predetermined) to simplify complicated phenomena. In this way, the existing stereotypes and myths are used. In addition, new myths are designed, which do not require either deep analysis or sound behaviour motives; instead they create specific clichés of thought. During information attacks, public space is dominated by specific information, while rational arguments are translated into information noise that is usually ignored by society. Information chaos prevents the truth from being disclosed. Such a situation allows using the techniques of absolute falsehood, which cannot be rationally denied because of persistent information noise.

Representatives of the Russian information geopolitics present the techniques used in information warfare as original and resulting from the information revolution. ${ }^{77}$ However, their comparison to the propaganda devices

\footnotetext{
${ }^{74}$ The concept of the domino effect has recently become very popular in advertising and public relations. See http://www.martinlindstrom.com/ 02112006

${ }^{75}$ Edward L. Bernays. Propaganda. New York: Horace Livelight, 1928.

${ }^{76}$ Leonidas Donskis, Gyvenimas pseudoivykių pasaulyje. Klaipèda, 20050718.

${ }^{77} \mathrm{See}:$ Панарин, Информационная война и дипломатия, 222-226.
} 
described by the US Institute for Propaganda Analysis back in $1938^{78}$ (see Table 2) revealed many similarities and repetitions.

\section{Table 2 Propaganda Techniques Identified by the Institute for Propaganda Analysis}

1. Name-Calling: an opponent is linked to a negative symbol; sarcasm is used against persons or ideas.

2. Glittering Generalities: virtue words are used against individuals or their actions, which are not based on proof or rational arguments.

3. Transfer: positive or negative phenomena or characteristics are compared without due argumentation.

4. Testimonial: a qualified source is cited to give greater emphasis to an idea.

5. Plain Folks: speakers attempt to convince their audience that they, and their ideas, are "of the people".

6. Card Stacking: positive information is provided about a person or idea, with op posing evidence being buried or ignored.

7. Band Wagon: appeals are made to follow the crowd and join in.

Source: Propaganda Critic. See http://www.propagandacritic.com/ 02112006

New influencing techniques are usually derived from traditional propaganda principles. Manoilo maintains that the e-media creates exceptional conditions to use manipulation techniques in geopolitical battles and lists them as follows: a biased selection of themes and topics; a fragmented presentation of information and the manipulation of information sources; the presentation of information to a selected social group; withholding information or the allocation of an disproportionately large segment of broadcasting time; the comparison of incomparable facts, phenomena, or individuals; manipulation by a biased adjustment of the audio and visual material; the selection or creation of a specific context for news or "compromat"; the manipulation of information for

${ }^{78}$ In 1937, the Institute for Propaganda Analysis was created by social scientists to educate the American public about the widespread nature of political propaganda. 
the purpose of creating fear, mistrust, disgust, and other such emotions; the presentation of opinions by biased experts as objective; the manipulation of reports or features to present negative opinions as unattractive or distorted; the manipulation of social questionnaires; etc.. ${ }^{79}$ Such a classification expands the understanding of the tools of influence and their application to a specific means of communication but, in actuality, it merely reflects the propaganda devices described by the Institute for Propaganda Analysis.

Georgi Grachev defines information warfare on the basis of the above mentioned and other manipulation techniques:

It is an art of influence aimed at making people act in such a way as they would never behave if they had accurate information relating to the event at their disposal ${ }^{80}$.

It should be noted that the media of today has created yet another exceptional media function, described by American sociologist Charles R. Wright, as the dysfunction of the media. Wright proposed that when the media alerted the public to a health risk, for instance, it was serving its news and information function, but if a public panic was created, this was a dysfunction of the media. ${ }^{81}$

Many analysts recall the famous radio adaptation of H. G. Wells' classic novel The War of the Worlds and the panic it created in Britain. ${ }^{82}$ Within this context, the studies carried out by the American medical epidemiologist Timothy F. Jones, where he analyses the impact produced by the modern media on the outbreaks of mass psychogenic illness, are extremely interesting:

Mass psychogenic illness involves people with real symptoms that are often triggered by misunderstood or false information. [...] Outbreaks of mass psychogenic illness often involve acute onset and rapid spread of symptoms, with minimal physical or laboratory findings. [...] Unfortunately, by the time many outbreaks are recognized as psychogenic illness, they have had a devastating effect on the communities and individuals involved. ${ }^{83}$

Timothy F. Jones believes that media coverage frequently escalates such epidemics of psychogenic illness. It is namely the media that exposes the symptoms of an illness. Later on, illness may escalate with vigorous or prolonged media response and its symptoms occur among a specific group of persons. Usually such groups do not have access to objective information or they do not believe in it. Although Jones is mostly interested in the medical aspects of mass psychogenic illness, its common characteristics, as described by Jones, are of immense importance within the context of information warfare:

\footnotetext{
${ }^{79}$ Манойло, (note 8) 121-122.

${ }^{80}$ Грачев Г.В. Информационно-психологическая безопасность личности: состояние и возможности психологической защитыь. РАГС, 1998. http://www.bookap.by.ru/psywar/grachev/oglav.shtm 02112006 ${ }^{81}$ Macnamara, (Note 17) 3.

82 Ibid.

${ }^{83}$ Timothy F. Jones, Mass Psychogenic Illness. American Family Physician, 200012 15. http://www.aafp. org/afp/20001215/2649.html 02112006
} 
- Often occurs after exposure to an environmental trigger (e.g., odour, emergency response, rumour, reported toxin, etc.);

- Individuals or groups of people with psychologic or physical stress are mostly affected;

- Closed communities are especially vulnerable (schools, occupational or religious groups, etc.);

- Symptoms spread by the media are instinctively imitated or reproduced;

- Symptoms spread rapidly - which allows treating this phenomenon as an epidemic. ${ }^{84}$

Earlier, such phenomena were studied as outbreaks of mass hysteria or panic. ${ }^{85}$ However, Timothy F. Jones was the first to accentuate the crucial role played by the media. It is the media that often triggers epidemics of psychogenic illness. In his analysis of potential information attacks, Russian political technologies researcher Gleb Pavlovski focuses on Russian opponents and their ambitions to translate technogenic calamities into mediagenic disasters ${ }^{86}$ This line of thinking is similar to that pursued by Timothy F. Jones.

It is thus possible to assert that information warfare, based on traditional propaganda techniques, allows not only to influence in a most subtle way the internal political processes of geopolitical opponents, but also enables to create and control mass political hysteria, built on the defects of modern media, in the information environments of other states.

\section{How to Guarantee Information Security?}

In the face of such a potential threat, ensuring information security emerges as an issue of key importance. Some efforts are made in the Lithuanian media, unlike in the academic circles, to discuss information security, however most of such public debates, with a few exceptions, ${ }^{87}$ result from information attacks against the Lithuanian society - they contain emotional evaluations hardly ever based on scientific arguments. In most cases, they create a climate of distrust in politics and the media.

In Lithuania, information warfare and information security research is yet at a starting point - several master degree theses have been written ${ }^{88}$ and some articles have been published in academic journals, also relevant academic discussions include only reports in rarely held thematic seminars. $\mathrm{PhD}$ theses

\footnotetext{
${ }^{84}$ Ibid.

${ }^{85}$ Wessely S. Mass Hysteria: Two Syndromes? Psychol Med, No. 17, 1987.

${ }^{86}$ Павловский, (Note 52).

${ }^{87}$ Leonidas Donskis, Informacinis karas ir naujasis kultūrinis kolonializmas. Klaipèda, 20050314.

${ }^{88}$ Nerijus Maliukevičius, Informacinis karas: JAV ir Rusijos požiūriai. Supervisor: Assist. Prof. Dr. Lauras Bielinis, Vilnius: Eugrimas, 2000.; Gytis Oganauskas. Informaciniai karai: priemonès ir jų panaudojimas. Supervisor: Assist. Prof. Dr. Audronè Nugaraitè. - V., 2001.; Marius Varnas, Informaciniai karai, jų priežastys ir tikslai šiuolaikiniuose kariniuose konfliktuose. Supervisor:. Tomas Deržanauskas. - V., 2005.
} 
written in Lithuania's higher educational establishments analyse only in part, the problem of information warfare: Tomas Janeliūnas focuses on the technical aspects of information security; ${ }^{89}$ and Darius Petrošius analyses information warfare tools from the prism of operational activities..$^{90}$ In these studies, little attention is given to the negative consequences of applying traditional information security instruments to open democratic societies.

The most recent studies of information warfare, both in the West and in the East, focus on technical or physical methods of dealing with information security issues. It is the logical result of the realistic paradigm, which continues to dominate in international relations:

Realpolitik has a natural reaction to the information revolution: It inclines strategists to prefer state control of informational stocks and flows, and to stress guardedness over openness. ${ }^{91}$

Rastorguev describes this kind of solution for information security as a strategy of "effective armour." ${ }^{92}$ Such armour can be put on ones own computer systems, like in the United States, or on the media structure or even on the whole of society, like in Russia.

Philip Taylor contends that the concept of prohibition is analogous to propaganda since both of them are different sides of the same coin intended for manipulating public opinion..$^{93}$ Technological means that guarantee information security cannot be applied to the psychological security of democratic information societies. This position may be illustrated by the following proposition made by Henrik Friman in respect of information warfare:

The question then is how to defend our mind, which in many aspects has characteristics that resemble the problem with computer viruses and Trojan horses, ${ }^{94}$ but that needs other solutions. In the computer world the best safety measure is to disconnect the computer from the surrounding world by using stand-alone machines, and access codes. This method is not suitable for individuals who need socialisation activities with others. Instead we need to find new ways for verification and authorisation that help us discover perception attacks. ${ }^{95}$

Some representatives of communication sciences propose pluralistic

\footnotetext{
${ }^{89}$ Tomas Janeliūnas, Komunikacinio saugumo koncepcija saugumo tyrimuose. PhD Thesis, Vilniaus universitetas, 2006.

${ }^{90}$ Darius Petrošius, Naujas konspiracijos principo turinys operatyvinėje veikloje. PhD Thesis, Mykolo Riomerio universitetas, 2003.

${ }^{91}$ Arquilla, Ronfeldt, (Note 28) 31.

${ }_{92}$ Расторгуев, Инфицирование как способ защиты жизни. http://www.koob.ru/rastorguev/virus 0211 2006

${ }^{93}$ Taylor M. P. Munitions of the Mind: a History of Propaganda From the Ancient World to the Present Day. Manchester University Press, 1995, 10.

${ }^{94}$ Type of virus, which violates computer security systems, paving the way for an unsanctioned use of the system's internal resources [N.M.].

${ }^{95}$ Henrik Friman, Perception Warfare: a Concept for the Future. Netherlands Annual Review of Military Studies (NLARMS): Information Operations, ed. J.M.J Bosch, H.A.M.Luiijf, A.R. Mollema. Haveka BV, 1999, 18.
} 
solutions to this problem, ${ }^{96}$ in particular when speaking about the regulation of the media. Such an approach to information security could be compared to the main principle of energy security - which is alternative energy supplies. In the energy sector, it means the diversification of natural energy resources, while in the case of information security it means the diversification of information and communication resources. In this way, power would be transferred from information producers and disseminators (potential manipulators) to the audience. It would thus become a power to choose, disbelieve and interpret.

Everest Shostrom, an expert in psychology, maintains that the best antidote against manipulation is actualisation. He juxtaposes lies with openness, apathy with activity, control with freedom, cynicism with confidence. ${ }^{97}$ The formation of communication etiquette in the state's information environment would greatly contribute to the neutralisation of information attacks. Intolerance of improper information provision methods, black technologies, or propaganda could level their impact by revealing the manipulator and his concealed objectives. In propaganda theory, this is described as source exposure. It is acknowledged that in this case, the ethical standards adhered to by journalists, public relations, and other specialists emerge as the principal tool. Without analysing different codes of ethics, we present below Johan Galtung's approach to communication ethics:

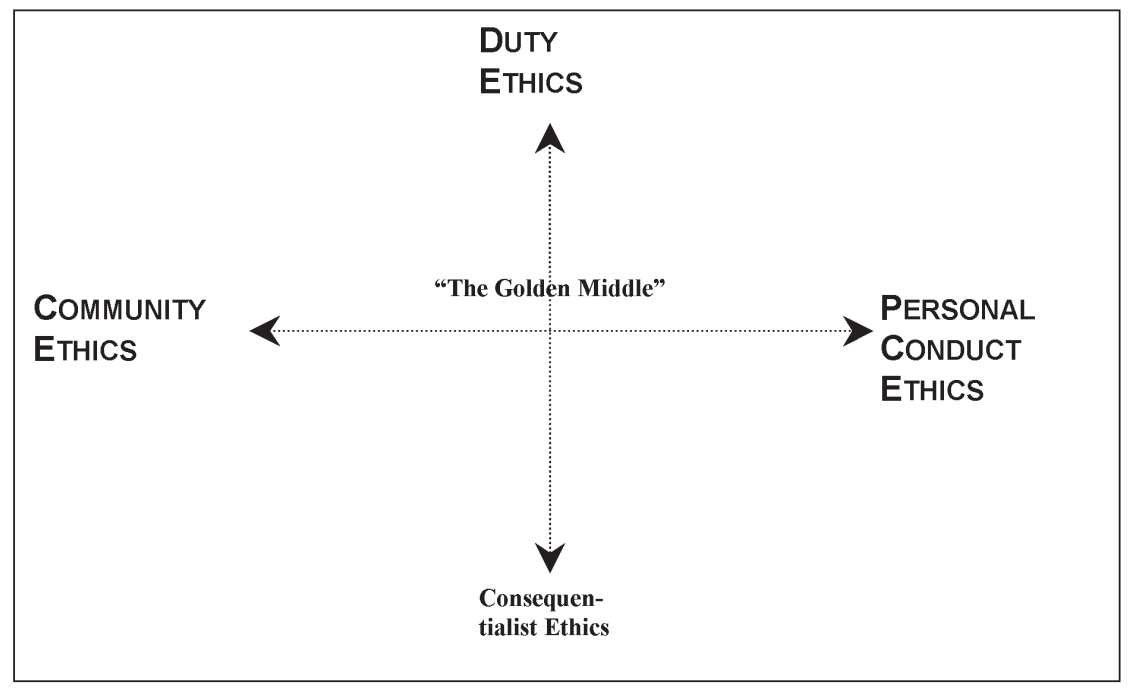

Source: Johan Galtung's Model. See Johan Galtung. State, Capital, and the Civil Society: The Problem of Communication. 1999.

Figure 7. Galtung's Model of Communication Ethics

${ }^{96}$ Macnamara, (Note 17) 3.

97 Эверетт Шостром, Человек-манипулятор: внутреннее путешествие от манипуляции к актуализации. K.: Psylib. 2003, 15. 
Johan Galtung urges to seek the golden middle in both, meaning the formulation of professional codes of ethics and in any action relating to communication. The aspiration to establish an idealistic etiquette of communication is directed at information producers and disseminators; however, there also exist approaches that focus on the possibility of the audience (consumers of information) to ensure its information security. Austrian e-media researcher Kondrad Becker focuses on the cultural intelligence level of an individual person and society. ${ }^{98}$ Becker maintains that an intelligent society should be able to distinguish manipulation techniques and eventually ignore them. In Lithuania, the issues of communication competence was also analysed, ${ }^{99}$ but the main emphasis was made not on the competence to deconstruct information, but on the ability to construct information and transmit it. Beata Grebliauskiene distinguishes the following skills relating to the receipt of information in intercommunication:

\section{Table 3. Classification of Communication Skills}

\begin{tabular}{|c|c|c|c|c|}
\hline \multirow{2}{*}{$\begin{array}{c}\text { Type of Com- } \\
\text { munication } \\
\text { Activity }\end{array}$} & \multicolumn{2}{|c|}{$\begin{array}{l}\text { Verbal Communication } \\
\text { Skills }\end{array}$} & \multicolumn{2}{|c|}{$\begin{array}{l}\text { Non-Verbal Communication } \\
\text { Skills }\end{array}$} \\
\hline & Written & Non-Written & Written & Non-Written \\
\hline $\begin{array}{l}\text { Ability to } \\
\text { receive Informa- } \\
\text { tion }\end{array}$ & $\begin{array}{l}\text { Ability to } \\
\text { read "be- } \\
\text { tween the } \\
\text { lines." }\end{array}$ & $\begin{array}{l}\text { Ability to hear } \\
\text { and recognise: } \\
\text { - verbal } \\
\text { speech; } \\
\text { - distinguish } \\
\text { intonations; } \\
\text { - etc. }\end{array}$ & $\begin{array}{l}\text { Ability to see } \\
\text { and recognise: } \\
\text { - symbols; } \\
\text { - text; } \\
\text { - photos; } \\
\text { - } \text { etc. }\end{array}$ & $\begin{array}{l}\text { Ability to see and } \\
\text { recognise: } \\
\text { - distances; } \\
\text { - postures; } \\
\text { - gestures; } \\
\text { - eye contact; } \\
\text { - etc. }\end{array}$ \\
\hline
\end{tabular}

Source: Beata Grebliauskienė, Komunikacinių mokëjimų struktūra ir turinys. Informacijos mokslai, No 7 (2), 1997, 52.

Communication competence could be thus defined as a Gnostic and operational-technical ability to participate in the process of communication, ${ }^{100}$ i.e. the ability to generate, encode and transmit information (thought), and also to receive, decode and understand information (thought). Grebliauskiene analyses common communication competences but she does not single out the ability to receive information from the modern media, in particular from the

\footnotetext{
${ }^{98}$ Konrad Becker. Cultural Intelligence and Social Control. Vienna: Selene, 2002, 69.

${ }^{99}$ Beata Grebliauskienė, Nijolè Večkienė. Komunikacinè kompetencija. Vilnius: Žara, 2004.

${ }^{100}$ Beata Grebliauskienè, "Komunikacinių mokèjimų struktūra ir turinys”, Informacijos mokslai, nr. 7 (2), 1997, 46.
} 
e-media. Such competence could be defined as "media competence", in analogue with the term "computer literacy." Today it is generally recognised that every member of the information society must have computer and IT skills. Therefore the formation of media literacy in the state's information culture should be among priority objectives with a view of teaching society to live in media reality conditions and neutralise information war offensives.

It should be acknowledged, however, that such a pluralistic approach to information security is exposed to the information war techniques discussed above when rational arguments and their advocates are discredited. On the other hand, fascination with bans and information regulation techniques may pose a serious threat to open democratic societies.

\section{Conclusions}

When Lithuania joined the European Union and NATO in 2004, its political goals were attained; however, the merger of the Lithuanian society, in terms of culture and values, with Western political and information environment still lacks clarity and stability. Russia's influence on the Lithuanian mass culture and the use of media products in Lithuania has become more pronounced. Some models relating to information geopolitical strategies and information warfare tools are used to gain control of Lithuania's information environment.

Russian information geopoliticians (Igor Panarin, Georgi Pochepcov and others) actively participate in designing and implementing foreign policy projects in the post-Soviet space. ${ }^{101}$ Such a situation confirms the exclusively close relationship between Russian geopolitical theories and political practices. Therefore, the theoretical approach presented above, which reveals the relationship between information geopolitics and information warfare, should contribute to the practical aspect of analysing Russia's policies pursued in respect of Lithuania.

The concept of information warfare created within the Western academic community engaged in military and security studies has been transposed to international relations and geopolitics. This tendency becomes particularly evident when analyzing works by modern Russian geopoliticians. It is therefore very important to understand how Russia uses information power levers to retain its influence in the post-Soviet space. It is also necessary to search for effective ways of ensuring Lithuania's information security.

It is essential to propose some alternatives to the current technical and physical information security methods, prevailing in both the West and the East, which would suit the needs of open democratic societies. It is therefore very important to publicly propagate communication etiquette, to provide society with guaranteed access to alternative information sources, and to raise its communication competence.

\footnotetext{
${ }^{101}$ These authors are members of the controversial forum Europe. See http://europeforum.info/users/?user session=6723ae06a71de0fc0b027e8f4a931884 02112006
} 
In addition, we should note that most of the information warfare studies in Lithuania and abroad focus on its tools, manipulation techniques, or the vulnerability of information systems. The relationship between the information warfare and morale is rarely discussed. This phenomenon should be analysed in Lithuania within legal and ethical contexts. It would create the required conditions to disclose the negative aspects of this phenomenon, which have until now received too little attention.

Vilnius, October - December 2006 